\title{
Female Arab Students' Experience of Acculturation and Cultural Diversity upon Accessing Higher Education in the Northern Galilee-Israel
}

\author{
Brenda Geiger ${ }^{1}$, Ph.D. \\ ${ }^{1}$ Western Galilee College \& Bar Ilan University, Israel \\ Correspondence: Brenda Geiger, Western Galilee College \& Bar Ilan University, Israel. E-mail: \\ geigerb@netvision.net.il \\ Received: July 8, 2013 \\ Accepted: July 25, 2013 \\ Online Published: July 30, 2013 \\ doi:10.5430/ijhe.v2n3p91 \\ URL: http://dx.doi.org/10.5430/ijhe.v2n3p91
}

\begin{abstract}
This qualitative study addresses the issue of the cultural transition of Arab women who for the first time leave their secluded villages and traditional society in the Northern Galilee to access Western-style Israeli institutions of higher education located in the region in which they will study in Hebrew, their second language. This study uses several models of acculturation in order to better understand these women's experience of acculturation, cultural diversity, ethnic identity and at times discrimination as they come into contact with students belonging to a diversity of Arab and Jewish ethnic groups. Content analysis of semi-structured interviews conducted with 42 female Arab students of Druze, Muslim and Christian origin, revealed that parental and/or husband support, lower college admission requirements, and the geographical proximity of the colleges to the villages allowed gave these women the opportunity to access higher education without compromising their traditional values of modesty and virginity. Hebrew language proficiency, seldom spoken in the villages, and consequent academic self-efficacy perception were for these women key factors for academic success and integration in the dominant Israeli socio-economic structures. Lack of tolerance for cultural diversity, discrimination, and inter-groups conflict were at times, reported not only between Arab and Jewish but also between Druze and Muslim students and/or their instructors. Factors mentioned to be reducing cultural shock and acculturative stress were the presence of other female Arab students from the same or neighboring towns studying in the college and the going back and forth between cultures as these women returned every day back home to their villages. Exposed to other values and traditions these women sorted the values they cherished in their own and in other cultures while maintaining a strong sense of cultural identity.
\end{abstract}

Keywords: Female Arab minority students, Multilingual, Multiculturalism and discrimination

\section{Introduction}

In this study Druze, Christian, and Muslim Arab female students speak of their experience of acculturation, ethnic tolerance, and discrimination as first generation of women leaving their villages of the Northern Galilee to access higher education in the colleges established in the region.

Prior to accessing regional Western-style colleges in which the official language of study is Hebrew, these women lived in secluded villages of the Northern Galilee in which only Arabic is spoken. Extended family and the communal life of the villages are regulated by Islamic or Druze laws and strict norms protecting women's modesty, and the honor of the family set the limits of women comportment and behavior (Abu-Rabia-Queder \&Weiner-Levi, 2008; Arar, \& Haj-yehia, 2010; Weiner-Levy, 2006). Arab students study in a separate educational system that aims at preserving the Arabic language, its traditions, and culture. Hebrew is taught as a second language since $3^{\text {rd }}$ grade, and English is taught as third language since $5^{\text {th }}$ grade.

Like other low SES minorities in the Western world, Arab and other Mizrahi ${ }^{1}$ minorities living in the periphery of Israel have come to grasp the importance of higher education as a means of social and economic mobility (Arar, \& Haj-yehia, 2010; Astin, 1982; Connor, 2004). However, Arab women's access to Western-style Israeli universities has often been met with the resistance of traditional extended families and community leaders due to the threat to female modesty. For many Arab families universities are insecure spaces in which young women may be tempted to transgress religious and ethnic norms protecting the honor of the family. Consequently traditional Arab families have been facing the dilemma of protecting females' honor by having them remain in the home versus allowing them to access higher 
education to increase the social and economic mobility of the family (Abu-Rabia-Queder \&Weiner-Levi, 2008; Arar, \& Haj-Yehia, 2010; Weiner-Levy, 2006). A similar dilemma was reported by female students from other Islamic countries such as Pakistan who were studying in British universities (Ahmad, 2001; Arar, \& Haj-yehia, 2010).

In addition to cultural barriers, low SAT and matriculation examination scores often prevented low income Arab and Jewish Mizrahi minority students living in the periphery of Israel to meet the high admission requirements set by Israeli universities (Abu-Saad, 2005; Al-Haj, 1995; Arar, \& Haj-yehia, 2010; Gamliel \& Cahan, 2004; Mustafa, 2006). Low psychometric scores have often been attributed to culturally biased examinations and/or the poor quality of education of self-contained Jewish development towns and Arab villages in the periphery of Israel (Abu-Saad, 2006; Al-Haj, 2003; Gamliel and Cahan, 2004; Mazawi, 2003). In contrast to wealthy families living in Arab towns who could afford placing their children in quality private schools and thus enable their children to obtain high matriculation scores, Arab and Mizrahi minorities living in the periphery of Israel are studying in public schools plagued with overcrowding and discipline problems (Abu-Asbah, 2005; Arar, \& Haj-yehia, 2010; Gamliel and Cahan, 2004; Mazawi, 2003).

To widen higher education opportunities for disadvantaged minorities United States and European countries have usually enacted affirmative action policies (Deardorff \& Jones, 2004; Ntiri, 2001; Shiner \& Modood, 2002). In 1992, the Israeli Commission of Higher Education's adopted the resolution to establish academic colleges in the Northern Galilee as a culturally sensitive solution combining the cultural demands with affirmative action policies (Al-Haj, 1995; Arar and Abu-Asbah, 2007; Budget and Planning Committee, 1997; Hershkovitz, 2000; Layish 1992). The establishment of academic colleges in the proximity to Arab villages, enabled traditional Arab families to resolve the dilemma they had been facing since their daughters had now the opportunity to pursue higher education without compromising the honor of the family as they continued to live at home and commuted daily to the college (AbuRabia-Queder, 2008; Al-Haj, 2003; Arar \& Haj-yehia, 2010). Additionally, and in conformity with affirmative action policies the lower admission requirements of the colleges when compared to those of the universities, resulted in a sharp percentage increase of low socioeconomic and traditional Arab and non-Arab Mizrahi minorities accessing the colleges in the Northern periphery of Israel. In contrast to the 11.4 percent of Arab students in Israeli universities, Arab students in the colleges of the Northern Galilee composed approximately 50 percent of the students' body (Weisblai, 2007). The percentage of female Arab students in these colleges was reported to surpass that of males, respectively $56 \%$ vs. $44 \%$ (Manna, 2008) and become approximately equal to that of Jewish female students (58\% vs. 66\%) (Council for Higher Education, 2009; Davidovitch, Soen, \& Kolan, 2007).

The experience of lower socio-economic status and ethnic minorities entering institutions of higher learning cannot be fully understood unless resituated within a space of encounter of knowledge, traditions and cultures at universities (Abu Rabia-Queder, 2008; Barnett 1993; Bourdieu 1988). Female Arab students, who had so far lived in secluded villages in which only Arab was spoken, will upon accessing higher education, have to study in Hebrew the official language of the college, and for the first time, come into contact with Jewish students of various ethnic backgrounds. Female Arab students were therefore, expected to go through a process of acculturation which has been defined by Phinney (2003) as a process of psychological, social and cultural adaptation that occurs when groups of various ethnic and/or cultural backgrounds come into contact with one another. Berry's $(1997,1998)$ basic model of acculturation includes four acculturation strategies available to ethnic and minority groups: assimilation, separation, integration, and marginalization. Ethnic groups may want to assimilate, that is, absorb their ethnic and cultural heritage into that of the dominant culture. Alternatively, they may want to integrate, i.e., maintain their own cultural heritage while weaving it into the dominant culture. Separation refers to ethnic groups' wish to remain apart to maintain their own culture and tradition while having little contact with the dominant culture. Separation, however, becomes segregation when forced by the dominant culture against the wishes of the ethnic group. Marginalization refers to a transient or permanent state of lack of identification and alienation from both the ethnic and dominant cultures.

The Interactive Model of Acculturation (Bourhis, Moïse, Perreault, \& Sénécal, 1997) expands Berry’s model to account for the interaction between the acculturation expectations of the dominant and ethnic groups and the degree of match and mismatch between them. Ethnic groups may expect to integrate while the dominant group may demand of them to assimilate or remain separate and, vise-versa. Within this model it is the degree of concordance of expectations of ethnic and dominant groups that will determine the intensity of the acculturative stress experienced by ethnic individuals and their perception of discrimination. Researchers have often stressed that the incidence of actual discrimination may be quite different from the levels of perceived discrimination reported by ethnic individuals. Perceived discrimination was also found to increase with greater cultural distance, mismatch of acculturation expectations and expression of ethnocentric attitudes by the dominant society toward their ethnic group 
(Gezentsvey, 2008; LeVine \& Campbell, 1972; Sodowsky \& Plake, 1992; Ward et al., 2001). Perception of discrimination has been linked to ethnic students' experience of higher stress levels, lowered self and/or group esteem, ethnic identity conflict, and poor work and school adjustment (Ward et al., 2001).

The Relative Acculturation Extended Model (RAEM) adds a multidimensional level to the Interactive Model of Acculturation by showing that the acculturation process is far from linear and domain specific. Ethnic individuals may want to assimilate in higher education, integrate their values with those of the dominant culture in politics, and in the economy, and yet maintain their own traditions and religious beliefs by establishing a separate educational system and life style (Navas, Garcia, Sanchez, Rojas, Pumares \& Fernandez, 2005; Navas, Rojas, Garcia \& Pumares, 2007).

In the space of higher education, in which Druze, Muslim, Christian Arab female students enter into contact with each other and with other Jewish ethnic groups Arab female students were asked to convey their experience of acculturation and perception of inter-ethnic group tolerance and/or discrimination in the colleges in which they studied.

\section{Method}

\subsection{Sample}

Sample included 42 women- among them 12 Druze, 22 Muslims and 8 Christians. The sample ethnic breakdown conformed with the ethnic composition of the Arab female student population in the two colleges under study. Selection of the research participants was as follows: In each of the respective college the names of the female Arab students was grouped in three lists based on their religious affiliation Muslim, Druze and Christian and the year of studies toward completion of the BA degree. Another selection criterion was that the research participants had to be in their junior year and up so that they could acquire the skills and perspective required to compare present to past experiences upon college entrance. The Dean of Students in the respective colleges were then asked to randomly select 12 Druze, 22 Muslim and 8 Christian female students from the respective list of students in their $2^{\text {nd }}$ to $4^{\text {th }}$ year of study. Except for 4 Christians and one Muslim living in Haifa and Acre, two large mixed Arab-Jewish towns in the North of Israel, all the other research participants lived in exclusively Arab towns and villages in the Northern Galilee. The participants' age ranged from 20 to 43 years old, with a median age of 22 . The majority of middle-aged women were of Druze origin who had in the past encountered the interdiction to pursue higher education. Another differentiating characteristic between ethnic groups was owning a driving license. Whereas all the Christian and half of the Muslim students in the sample owned a driving license, none of Druze students did. This fact is explained by the prohibition placed on religious Druze women to drive a car. Non-religious Druze women who wish to get married or be buried religiously must surrender their driving license to their religious leader, the sheikh. These restrictions were seldom reported by female research participants of Muslim and Christian origin (Al-Haj, 1995; Golub, 2009; Hasam, 1999; Nissim, 2003). The importance of owning a license cannot be enough stressed given the scarce public transportation to and from the villages of the Northern Galilee which often rendered female students dependent on family members to drive them to the college.

\subsection{Research Instrument}

In-depth interviews utilizing a semi-structured interview guide research instrument with open-ended questions (Corradi, 1991; Rosenthal, 1994) was the most appropriate research tool to allow the research participants to convey their subjective experience of encountering students from various ethnic groups and the challenges they had faced when studying in Hebrew, their second language. These women were asked to share their experience of acculturation and perception of cultural diversity, and inter-ethnic groups discrimination in the colleges in which they study and to envision ways to increase respect and multi-ethnic integration.

\subsection{Procedure}

Participants were contacted by phone to explain the purpose of the study and obtain consent prior to conducting the research. The anonymity was guaranteed and all names were replaced by pseudonyms to which was attached the religious affiliation of the participant so denoted, e.g., Nadia, Druze. Interviews started as an informal conversation with three completely open-ended questions: "Do you remember your first day in the college? How did you manage? How do you compare yourself today and then?" As the conversation progressed it became more focused and followed an interview guide to guarantee that all the topics would be covered in all the interviews. The interviews were each time conducted with a pair of female students to respect the norm that young Arab women must always be accompanied by another woman. The interviews lasted approximately two hours and were conducted in Hebrew and Arabic by an interviewer who also was bilingual, with much code switching integrating both languages in the same 
sentence as is common with multilingual speakers (Liebkind 2001). Interviews took place in one of the offices of the college, and permission to tape the interview was obtained with the understanding that the recording would be stopped any time the participants wished to do so.

To allow for the student's answers to naturally flow and to keep interference to a minimum, the order of the questions appearing in the interview guide was not always followed. Additionally, the interviewer waited for the interviewee's pause between questions to ask for examples and clarification.

\section{Data Analysis}

Content analysis of information-rich interviews followed Strauss' (1987) constant -comparative method and Patton's (2002) guidelines of analysis. Interviews were transcribed and transcripts were read several times to uncover similarities and differences in the narratives. In so doing, the researcher was able to identify repetitive categories and themes that reflected shared experiences and common meanings related to Arab female students' shared experience of accessing higher education, while having for the first time to study in a second language, Hebrew, and come into contact with students of various Jewish and Arab ethnic groups (Lincoln \& Guba, 1985).

Analysis of the interviews relied solely on the subjective meaning and interpretation that the interviewees gave to their experiences, and on the feelings and thoughts they attributed to them. The question of "objectivity" and fact validation did not arise in this study (Bruner, 1990; Denzin, 1989; Holsti, 1969). Nevertheless, recurrent and common themes and episodes evoked by the interviewees increased the reliability of the findings. Furthermore, all inductively drawn themes were supported with direct quotes from the narratives. In such a manner, the reader could verify the validity of the author's inferences and comprehend the interviewees' experience in their own words and from their own perspective (Bruner, 1990; Krueger \& Casey, 2000; Patton, 2002).

Results

\subsection{Religious community leaders' attitude toward higher education}

The geographical location of the academic colleges and their proximity to the villages and towns often rendered Church priests and Muslim Sheikhs more willing to have women access higher education. Muslim interviewees stressed that although some religious leaders were scared to see women leave the village, things have changed and their opinion counts much less than in the past.

Our religion forbids women to go out of their house and that men see them. So they are scared that women go out to study. We cannot easily change religious people's position on this matter. They think that what they say is sacred. But this belief is often ignored. We have changed and progressed and women's condition is better than what it was . (Fatana, Muslim)

Evidence in support for higher education were the scholarships offered to female students by respected elders of the village. In the words of the Muslim students,

In our mosque the sheikh give scholarship for men and women. This is the third year that I have been obtaining one. (Olfat, Muslim)

We have charitable religious organization that offer women a scholarship. (Magdira-Muslim)

In contrast, Druze Sheikhs resistance to higher education was reported to be strong as expressed by the lack of scholarship for women. In the words of Druze interviewees,

I belong to a religion that is very conservative and limits women. In our religion, women do not need to read and develop; they just need to know the basics so that she can read prayer books. The Sheikhs do want women to go to the university. They want girls to stay home, get married and have children. (Rashat, Druze)

They do not give scholarship. This would give legitimacy to learning. (Soal, Druze)

After many years when the racist Sheikhim will die and more educated people will take their place and become Sheikhim things will be different (Aymat, Druze)

\subsection{Facing the elderly women's gossip and resistance}

In a tight community in which they lived often exposed the students interviewed to the gossip and rumors of elderly women who watch them leave their village. To the interviewees these women lacked of any appreciation for higher education and did not hesitate to comment on their leaving the village. In the words of the interviewees,

In the Arab sector they do not value women's education. If I do not get married, they will not respect me. They always look at you as if something is missing in you. Even if you have a masters or a Ph.D., they stress what is 
missing. (Madgira, Muslim)

Some women say: "Go and study!" But they are not in great number. Most of them do not encourage us. They say: "Where is she going? She is going to study; I wonder if she will also go to another place instead of going back home." They say: "What will you gain from it? Get married, go find a husband." (Holud, Druze)

In my neighborhood they look at me. "What! She is studying!" Older women who did not study do not support us. They tell me, "Stay home and educate your children" I only study two days a week. (Ahalm, Muslim)

\subsection{Extended family support a condition sine qua none to higher education}

Given the community elders' resistance to have women leave their village and the priority of being married and having children, pursuing academic studies demanded the intensive support of the extended family. In the words of Soher,

It depends of the family. Some families push their daughter and others prefer that their daughter gets married and stay home and forbid her to study. (Soher, Muslim)

Some of the girls I know did not go to study because their parents were scared to let them go for fear that they will be humiliated by their daughter behavior outside the home. (Fatima, Muslim)

Holud (Druze) spoke of her father as an ally ready to take her side and confront the opposition of a friend of the family. In the words of Holud,

In my opinion it starts with the father and the mother. When I graduated high school my father said: "Go to college". His friend said: "Why? Why does she need a degree! She should go to work." (Holud, Druze)

Once engaged or married the interviewees had to face the support or opposition of the spouse, Fatima reported the support of her husband,

My husband supports me and pushes me to study and work. He likes independent women and not a woman closed at home and knows only to have children. (Fatana, Mustlim)

In contrast, Magdira (Muslim) recounted that she had to break up with her fiancé who no longer agreed to let her pursue her studies. In her own words

He was too conservative. At the beginning he accepted that I study, but after two months he changed his mind.

He told me. 'You are not allowed to go to study or work.' I could not stand it and I left him. (Magdira, Muslim).

\subsection{Advantages of studying in colleges as opposed to universities}

To show the benefits of studying in the colleges of the Northern Galilee the interviewees invariably compared these colleges to the universities in Israel. They often reported that their psychometric scores were too low to meet university admission requirements. In contrast, more lenient admission requirements of the regional colleges in which they studied gave them the opportunity to pursue academic studies. In addition, the proximity of the colleges to the villages was mentioned as an additional asset reducing the tedious hours and cost of transportation, living expenses, and traditional parents' resistance, since they could continue to live at home. Some of the interviewees who had for a year pursued their studies at Haifa University mentioned the long bus rides when commuting every day, back and forth, from the village to the university. Halud who subsequently transferred to the college explained,

I studied psychology at Haifa University. The bus rides were two hours long. I had to go from Yirka to Acre and from Acre to Haifa central station and from there take another bus to the university. The ride was hard. Here it is much easier. (Halud, Druze)

\subsection{Proximity of the colleges: A solution to sleep away from home}

Similarly, Nura (Druze) who tried commuting begged her mother to let sleep in the dorms. Her request was vehemently rejected by her religious mother and she transferred to the college in the region. In the words of Nura,

I told my mother I cannot commute anymore. Either I sleep in the dorms or I stop studying! So my mother who is religious said: "Stop studying!" I tried to convince her, but it did not work. So, I heard that there was a college here. (Nura, Druze)

Ahlam, Muslim also stressed that girls must sleep at home and thus the importance of having academic colleges in the proximity of their village. In her own words,

You cannot sleep away from home; it is a question of family honor. Even if I want to do so, they will not agree. You are obligated to accept what they want me to do. (Ahlam, Muslim) 
Similarly, Fatima reported the fear of having girls leave outside the home

I leave in a relatively more developed village and the elders of the village are proud of girls who study but they are against women who leave their home to study. They are scared that when they sleep outside the home they will do things that are not allowed in our society. (Fatima, Muslim)

\subsection{Decreasing feeling of otherness and cultural shock}

Studying in regional colleges as opposed to Israeli universities was also reported to decrease the feeling of loneliness that some of the interviewees had experienced prior to transferring from the university to the college. Colleges in proximity of the villages were for the interviewees a safe space in which they could meet other female students from the same or nearby village and help and support each other. Nur explained,

When I went to study at the university I was young, 17 years old. I was alone without friends. My friends were not admitted and I was the only one to be accepted. So I started to commute alone, I went to classes alone. I did not have friends. Here I found friends. I have a friend from Yarka and other friends. (Nur, Druze)

The culture shock of facing a different culture and having to communicate in Hebrew was often eased when collectively experienced collectively with other female students of the same ethnic background. In the words of Shirin,

The first day is the hardest. You arrive from the village, you wonder if you will know people. It is a new environment and a new way of learning. I met Soal from the minute I arrived, and since then we are together. (Shirin, Druze)

\subsection{Studying in Hebrew and being exposed to different modes of thinking}

Language mixes with culture and so do modes of thinking and acquiring information (Driessen 2000; Vedder 2005). The interviewees invariably mentioned they had to confront a different mode of thinking and acquiring knowledge to which they were not accustomed. In the Arab sector, throughout high school, rote learning of the material dictated by the teacher was the rule. In college, the interviewees learned to take notes, participate in class, ask questions and argue with the instructors. In their own words,

In the beginning it was very hard for me to focus, to follow and to understand what the teacher said. But after a year it all changed. Today I have more experience. I have been exposed to different way of learning and studying. I can follow what teacher say, argue, write papers and study efficiently. (Fatima, Muslim)

In high school, they dictate to you. Here you must learn what you understood, you write, (Nahaya, Muslim)

At the beginning, I did not know what to write, what is important and what is not. I did not know this method [taking notes], and I did not know the language. I had to learn the method and the language. (Rafat, Druze)

\subsection{Modeling students from other ethnic groups}

The interviewees reported observing and modeling Jewish and Christian female students, in order to learn the proper classroom behavior and efficient learning strategies for successful academic performance. In their own words,

Jewish students are more active. They participate and ask questions. We do not have this, maybe because of language problems. (Roseen, Christian)

We learned that we must ask questions. At the beginning you are scared, you feel embarrassed, you are not sure of yourself. I did not know how to ask. I learned from the Jewish students and from other students. There are also some Arab students who are strong. (Druze-Nura)

To the query from which Arab students had learned, Rabya responded: "Christian female students! The other students are embarrassed." (Rabya, Druze).

\subsection{Variability in Hebrew language mastery: Towns vs. Villages}

Hebrew language mastery was, invariably mentioned as an essential component of classroom participation, and successful academic performance. The interviewees explained that even though they had learned Hebrew since third grade, and had studied advanced Hebrew up to $12^{\text {th }}$ grade, oral Hebrew proficiency depended on the opportunities they had to speak Hebrew. Female Arab students growing up in villages seldom were exposed to oral Hebrew, and rarely had the opportunity to communicate in this language. In contrast, those residing in multi-ethnic towns such as Haifa or Acre had ample opportunities to speak in Hebrew and therefore, experienced very few communication problems upon entering college. In the words of the students,

The teachers gave us essays to write, but this is not enough. Five point Hebrew is not enough. It is important to 
start speaking from middle school. We must have more discussions in class and have all the students speak in Hebrew. (Madgira, Muslim)

Girls from the villages do not know Hebrew. In their village they do not speak Hebrew and you do not go out of your village. Everyone speaks only Arabic. (Lilian-Christian)

In town, you are more exposed to Hebrew. Those who speak Hebrew come from town, not from villages. Their Hebrew is better. Those who come from villages are scared to speak. (Madgira, Muslim)

We must improve the study of the Hebrew language, especially in the villages, because they have little contact with the Jews as we do in Haifa. We learn Hebrew since we are little children. I have no problem communicating in Hebrew. (Rosane, Christian-Haifa)

\subsection{Hebrew language mastery, and consequent feeling of self-confidence}

The students interviewed often mentioned the feelings of inferiority experienced by female Muslim students coming from villages. Magdira explained that this feeling was directly related to their inability to communicate in Hebrew. In the words of Magdira,

Some of them think they are inferior to Jewish students. They have an inferiority complex. They are embarrassed. They do not participate in class. (Magdira, Muslim)

Lack of self-confidence was often exhibited by keeping silent during lectures. In the words of Rafyat,

Usually they keep silent because they lack self-confidence. Students who are loud, they listen to them. I once told the professor, "I asked you a question and you ignored me!" She was surprised. If they ignore you, you have to speak up! (Rafyat, Druze)

Over the course of their BA studies, the interviewees from the villages however reported mastering the Hebrew language and becoming increasingly more confident in themselves and their abilities to perform the required academic tasks. Rabya explains,

In the first year, there was a difference in self- confidence. I was 19. I did not speak; I was scared that I make mistakes and they make fun of me. It was breaking my heart that I could not ask questions. Today [three years later] I can ask questions, and even argue with the instructor. This gives you self-confidence. All in all, it is a matter of self-confidence. Over the three years, it goes up. (Rabya, Druze)

In the first year, I did not speak because of my mental state. But in second and third year I participated in class. I always tried, even when I did mistakes. Even if I said or wrote a word with a mistake, I wanted to learn more also the language. I know that I have to improve. (Madgira, Muslim)

\subsection{Studying in Arab speaking}

For the female students interviewed, pursing higher education in Arabic as some of their Muslim friends did when enrolling in Arab-speaking colleges of the Galilee, was not a realistic solution. To be integrated into the Israeli social structure and obtain a well-paying job they had to master Hebrew, the official language of the state of Israel. In their own words,

I prefer to study in Hebrew. It is the first language of the state; we have to know it. (Amal, Muslim)

We have to know the Hebrew language well. In order to succeed in Israel we must know Hebrew. (Hanaya, Muslim)

My Hebrew improved; it is on a much higher level. I am now thinking more in depth. I am not ready to give up on Hebrew. (Mary, Christian)

Studying in Hebrew has given me a lot more confidence in myself and more knowledge that I did not know. (Fatima, Muslim)

\subsection{Instructors' openness to cultural diversity and expressed support}

When speaking of the experience of studying in culturally diverse classrooms, the interviewees invariably mentioned the respect and support of instructors who valued their efforts and encouraged motivation. In their own words,

I really like it here. There is a special relationship of the instructors to their students. I always showed motivation and they always showed their appreciation. In our sector appreciation for women is lacking. (Magdira, Muslim)

They like us. (Amal, Muslim) 
Openness to cultural diversity meant for the interviewees equal treatment of Jewish and Arab students. Professors who were open to cultural diversity encouraged Arab students to speak up and express their opinions and were valued as tolerant and fair. In their own words,

If they allow us to speak in class it is a sign that they support us. I really did not see discrimination. From the beginning they related to us well. (Nura Druze)

Equal treatment. I did not have instructors who do not relate to me because I am an Arab.... Except for one teacher! (Rosane, Christian)

Teachers related to all students from Jewish and Arab sectors the same. (Areen, Mulsim)

For the interviewees, tolerance for cultural diversity also entailed understanding the difficulties female Arab students were facing when accessing higher education and taking proactive steps to help these women along the way. In their own words,

Instructors support us, no problem. They know that female Arab students have many difficulties. They try to help as much as possible. (Mary, Christian)

In their opinion, instructors open to cultural diversity knew how to empower female Arab students who did not dare taking any initiative. In the words of Magdira,

Arab women do not have initiative built inside of them. Professor A helped, she pushed, explained. Professor B encouraged and stressed participation by adding points to our grades. (Magdira, Muslim)

Mary described the ideal college professor in culturally diverse classrooms,

A professor sets an example of multiculturalism is an ideal role model. He allows all students to ask question, shows them that they are equal and does not allow anyone to despise them. A multicultural professor gives strength to each one of his students by putting her at the center, so that she can improve and do better. A multicultural teacher understands that one student is different from the other. (Mary-Christian)

The students' interviewed shared the unforgettable classroom experience of interacting with instructors open to cultural diversity. In the words of the interviewees,

It was great to be in class and listen to them. They were also ready to stay after class to listen to the students and help as much as possible. (Roseen, Christian).

Most of the instructors are accepting us; I am thankful for their special consideration. It helps me calm down and encourages me to succeed. (Juliana, Christian).

\subsection{Entering in contact with Jewish students}

When asked to comment on their relationship with Jewish female students, several of the interviewees mentioned the Jewish friends they had made and the help they had received from them during their first steps in the college. They explained,

I do not have any problems. I have Jewish friends. (Mary, Christian)

From the beginning, Jewish girls helped us. We started to talk, and it helped. (Nahaya, Muslim)

I am very friendly. I do not have problems talking with students from other ethnic groups. I work with a group of students who are all Jewish except for me and I get along with them very well. (Nehad, Druze)

Very often, however, the geographical distance separating villages from towns, the lack of driving license, and inadequate public transportation were often severe handicaps to continued contact between Jewish and Arabs students who studied in the same college. In the words of Lilian,

It is possible to have Jewish friends, but the distance has an influence on the friendship between Jews and Christians in villages. We went once to them, but it was far. Sometimes we meet in Acre. (Lilian, Christian)

I do not have a problem with visiting Jewish friends, but I rarely can do that. (Rosane, Christian-Haifa)

I am in touch with other Druze and Jewish students but this contact is very superficial and only within the framework of our studies (Fatima, Muslim)

\subsection{Inter-ethnic groups conflict and discrimination on Campus}

The topics of lack of tolerance of cultural diversity and discrimination were at first dismissed by the interviewees. However, as the interview progressed in Hebrew and Arabic and rapport was established, the interviewees felt more 
at ease and psychologically safe to address these topics. They mentioned the lack of tolerance and respect of Jewish professors for Arab students in general and of Arab professors for their own ethnic group. Jewish professors were perceived to discriminate against Arab students as evidenced by the verbal and nonverbal messages they communicated. Ignoring Arab students' attempts to participate in class, giving demeaning looks, and/or sarcastic comments were some indicators of discrimination reported by the interviewees. In the words of these women,

Not in grades, but in the way they relate and speak to you. It makes you feel that they despise you. Some of them make as if they did not hear you. She keeps on talking and ignores you. (Amal, Muslim)

Looks, letting you feel that you are not equal from the way she talks and relates to you, and ignores you. There is a teacher here who really makes you feel that you are not equal. (Magdira, Muslim).

There is everywhere racism. Sometimes it also happens in the college. When Arab and Jewish students start arguing with the instructors, the instructors will only relate to the comments of the Jewish students. (Shirin, Druze)

Lack of tolerance and discrimination between Arab students and Jewish instructors as well as between Arab professors and Arab students of various ethnic groups did not only relate to academic topics. Between ethnic-groups tension was intensely felt during political debates on Palestinian issues. Druze interviewees who identified themselves as Druze and Israeli and who had brothers serving in the I.D.F (Israeli Defense Force) felt particularly stigmatized and at times rejected for being Druze by Muslim as well as by Jewish professors. They perceived Muslim professors to be condemning them for not adhering to the cause of oppressed Palestinian people and Jewish professors for being part of Arabs groups defending the Palestinian cause since they spoke Arabic. In the words of Halud,

Some professors do not look at you like Druze who serve in the army like them! You speak Arabic! So you are an Arab. He is from another origin. But I am a Druze and Israeli. (Halud, Druze)

Rabya, a Druze student, mentioned the hostility of Muslim professors against her people. Yet she did not remain silent, and reported the incident to the Dean of Academic Affairs. In her own words,

We were speaking about nationalities and we spoke about the Druze. And the professor said the Druze do not have a nationality, they are oppressed and are taken advantage of by the state of Israel. I told him you have no right to talk like that! And I went to speak to the Dean.

\subsection{Lack of tolerance between ethnic groups}

When addressing the degree of inter-ethnic group tolerance between students, the interviewees often perceived Jewish as well as Arab students to be engaging in a process of mutual selection and differential discrimination based on ethnicity and religion. Druze students felt more tolerated by the Jewish students than Muslim students were. However, based on the verbal and nonverbal messages Jewish students conveyed to them, they felt less than equal. Rafyat, a Druze student used the phrase "levels of friendships" to indicate Druze students were lower in the scale of friendship than Jewish students. In her own words,

The Jewish students relate to the Druze better than to the Muslims, but we still do not feel equal. It is like they have levels of friendships. A Jewish student does not speak with a Druze student the same way as she speaks with a Jewish friend. (Rafyat, Druze).

In general, there is a good relationship and mutual understanding between ethnic groups. However, at times we feel tension in the air that makes you feel uneasy (Juliana, Christian).

The students interviewed often desired integration, but perceived other Arab and Jewish ethnic groups as wanting to maintain separation and inter-group boundaries. Separation was inferred on the basis of ethnic students' seating arrangement in the classroom. In the words of some of the students,

I sit here and a Jewish student sits there. I do not think there is contact between us. In class we all ask questions, but there is no contact. (Rafyat, Druze)

Interviewer: Because of the language?

Shirin: No! My head is different from their head. There some Jewish students who would prefer that somebody like me does not talk to them. (Muslim)

Naheya, however, remarked that the choice of separate sitting arrangement did not necessarily mean exclusion or segregation. Female students of the same ethnic group often sat together in class and in the cafeteria simply because they felt, just as she did, more comfortable with students of the same ethnic group. 
In class Jews sit on one side and Arabs on another. Everyone sits with the people they identify with. (Naheya, Muslim)

The interviewees mentioned derisive comments and looks of hatred as additional evidence of discrimination and lack of ethnic tolerance between Jewish and Arab ethnic groups. In their own words,

I don't know, I always think there is discrimination. For instance, here in the college, well, I feel that they are looking at us. (Halud-Druze)

There are some students who do not treat us right. They give us looks, this special kind of look! This is especially true when we participate in class. I felt it in English classes. (Rosane, Christian)

Lack of ethnic and cultural tolerance and perceived discrimination was also reported between Arab students based on the ethnic group to which they belonged. Muslim students reported being the target of discrimination and prejudice not only of Jewish but also of Druze students who gave them condescending looks. They viewed Jewish and Druze students as considering Muslim students to be underdeveloped and dirty.

There is some discrimination. Jewish students look at us as if we are underdeveloped. (Soad, Muslim)

They think that if she is an Arab Muslim, therefore she is dirty. I heard it. They did not speak about me, but about someone else. Everyone is scared to speak that there might be a war. In my heart I feel that their words are dirty, a very low level. I thought what a sad situation. She is a human being too, and there is so much hatred! (Madgad, Muslim)

Amal explained,

Amal: In our village live Muslims, Christians, and Druze. We have better relationships with the Christians.

I: Do you also speak with the Druze students?

Amal: Yes, but they are worse than the Jews.

I: Why?

Amal: They speak as if they are the best in the whole world.

Inter-ethnic group conflict was sharply experienced by Druze female students when interacting with Muslim students. Exclusion and hostility were particularly felt in times of war and political crisis when Druze female students who perceived themselves as Arab Israelis wanted to participate in Arab students' meetings. In those meetings Druze students were often the target of verbal abuse and rejection just because they had brothers serving in the Israeli Defense Force. In the words of some of the Druze students interviewed,

I will tell you I am a Druze Arab who lives in Israel. I identify myself as a Druze Arab. I have two brothers in the army. My father served 25 years in the army. It is hard to hear them [Muslim students] say that the Druze are traitors! I do not like how things are! My brothers were on the front! The state of Israel exists! This is a fact! (Rafyat, Druze)

They make us feel that they are racist. The Muslim female students give us looks. During the war I was on both sides. There are children in Sderot and there are children in Gaza. They are also children. (Nur, Druze)

What hurts most is that Arabs like us despise us. They said "Death to the Druze." I heard this several times. So I left the meeting, because if I start speaking, I will really hurt them. It is very hard to accept their views. They see us as having ties with the oppressor! (Shirin, Druze)

\subsection{Fighting discrimination}

The interviewees often placed college professors to be at the forefront of discrimination. Discrimination and prejudice were attributed to some instructors' ignorance of basic notions of humanity included in democratic principles. To the interviewees, every student in the college was entitled to respect and dignity owed to people as people. In their own words,

Not to judge people from the outside, to look at them from the inside. To accept people as people, not to judge based on their race and ethnic group. We are all people, we are all equal. They should finally get rid of their views that the Arabs are primitive! (Roseen, Christian)

Maybe we should improve the ideas of professors, that they take classes on democracy and equal opportunity! (Shirin, Druze)

The interviewees who wished for integration in higher education contended that instructors' stereotypical conceptions 
could be changed with increasing awareness of the battles Arab women had to fight to access higher education. In their own words,

I would like instructors to respect the difficult road and battles of female Arab students who must convince the whole world in order to reach higher education and study in college. (Mahaya, Muslim)

I would have like that they support us more, that they do not think that we are inferior and do not despise us. Every one learns from mistakes. Teachers should grade us differently than Jews and take into consideration the difficulties of Arab women are facing. (Fatana, Muslim)

The interviewees also believed that exposure to the richness of their cultural heritage would help fight prejudice and discrimination. In the world of the students,

I would recommend that these professors read about the achievements in the Arab culture and that they liberate themselves from prejudice. What's most important is to liberate oneself from stereotypes, to treat everyone equally. That's the only thing that works. (Roseen, Christian)

Equally important in the fight against racial and ethnic intolerance was empowering students to speak up and report any form of discrimination. In their own words,

We should act toward each other with respect and fight any acts of racism - no matter from which ethnic group it comes from. This would improve our mutual respect among groups. (Amal, Muslim)

Never keep silent, complain and fight any sign of discrimination or racism. Some students get used to it, they keep silent. But if it happened to me I would not. (Shirin, Druze)

Dialogue and participation in joint projects were proposed to increase inter-group contacts, Hebrew language proficiency, and multi-cultural integration. In the words of the students interviewed,

We need contact and communication between members of various ethnic groups, dialogue between groups or between students and instructors. (Amal, Muslim)

I propose open-group discussions between students and professors during which we can exchange ideas and get acquainted with each other's culture. Dialogue strengthens ties between groups. (Ahlam, Muslim)

\subsection{Integrative multicultural perspective}

Just as the female Arab students interviewed requested from instructors to change and broaden perspective, they reported that over the three years they had studied in the college, they themselves had changed and learned to get rid of their misconceptions concerning other ethnic groups. Appreciation of ethnic and cultural diversity meant noticing the fine differences within and between ethnic groups and villages. Sohar and Ahlam, two Muslim students living in neighboring towns in the Galilee, noticed while sitting next to each other in classes the almost unnoticeable differences between the traditions and dialect of their respective Muslim towns. In the words of Ahlam,

There are words she pronounces another way. There are words that we pronounce longer or shorter. From the way people sound their words you can know if they are from Sachnin or Arabe. There are also differences in customs. (Ahalam, Muslim)

Inter-ethnic Arab groups contact often increased the interviewees ' interest and curiosity in other traditions and religious practices. Shohar, a Muslim student, commented: "I always ask Druze students, 'Why do you do this or that'." Ahlam, also Muslim, mentioned the differences in comportment and attire among female Druze students from different villages. She commented: "Druze women from Shahu are more modern than those from Yorka."

\subsection{Multiculturalism in the eyes of the participants}

Multiculturalism for the students interviewed also meant wanting to incorporate in their culture what they valued in other cultures. The interviewees invariably mentioned Jewish girls' sense of autonomy, independence and selfconfidence that they would have wanted to incorporate in the education of Arab women. In their own words,

Jewish girls are educated to be more free, more independent with more self- confidence. Jewish girls are more independent and self-responsible. The basis of women education in our tradition is to watch for girls and the honor of the family and not to teach girls how to watch for themselves. (Naheya, Muslim)

They also aspired to greater equality between men and women that they were exposed to in the college. In the words of Fatima,

Arab women are taught that they are weak and that she is a woman and not a man and that she has to behave accordingly. I would change women status in our society that there be more equality between men and women. 
I would try to change male perspective on women and in relation to their superior status. I do not see any change in perspective in the horizon. (Fatima, Muslim)

Despite the value that attached to Jewish girls' freedom, autonomy and independence, yet they invariably condemned their sexual freedom. The Druze, Muslim, and Christian female students interviewed valued the protection of women's honor and virginity, a value shared in common by their respective traditions. In their own words,

The most important value in our tradition is the honor of the girl. Some girls do not watch for themselves. They allow us to be independent, but this is not freedom - we have to preserve our honor. (Ahlam, Muslim)

Religion and tradition are part of our life. Jewish girls go out to pubs and clubs on Fridays. In our tradition it is different. (Yasmin, Druze)

I am very proud of being Druze. Tradition is very important to us. It protects us within the framework of our religion. What religion requires from Druze girls to do we do. And what is the most important is that our religion allows us to grow while protecting us at the same time. (Henad, Druze).

Openness to ethnic and cultural diversity also meant to these women being proud of differences that they wanted to preserve in their own culture and ethnic identity. In the words of Roseen,

We cannot deny that we are culturally different, and we have to accept those differences. Sometimes they make you feel different... but I have self-confidence. If I feel different, I feel different in a good way. We cannot deny the fact we come from another culture. I see myself as a Christian who is part of the state of Israel. (Roseen, Christian)

But I would not want to adopt the Israeli culture in all it forms. I see myself as Muslim, traditions and Honor are important to me (Fatana, Muslim)

\section{Discussion}

This qualitative study addressed the issue of the cultural transition of Druze, Muslim and Christian Arab women who, for the first time, left their secluded village and traditional society in the Northern Galilee to access Western-style Israeli institutions of higher education in which they had to studies in Hebrew, their second language. During in-depth interviews 42 female Arab students from various ethnic groups conveyed in their own words and from their own perspective their experience and expectations of acculturation and cultural diversity and at times, of discrimination in the two colleges of the Northern Galilee in which they studied. The findings of this research support the Interactive Model of Acculturation (Bourhis et al.1997) by showing that the perceived degree of concordance or match and mismatch between various Arab and Jewish ethnic groups' cultural expectations determined to a large extent the degree of perceived discrimination and rejection as well as the degree of academic well-being experienced by ethnic minorities. Female Druze students' expectation of integration with other Arab and Jewish ethnic groups often conflicted with what they perceived to be other ethnic group expectations-separation and at times segregation. As a result, Druze women felt stigmatized and rejected not only by Jewish but also by Muslim students and/or instructors. Similarly, female Muslim students who perceived Druze students as condescending, feeling superior and wanting segregation often rejected those they perceived as rejecting them. In addition, Muslim students' lack of self- confidence and poor Hebrew language mastery often made them feel marginalized by Jewish students.

In conformity with the Relative Acculturation Extended Model (Navas, Garcia, Sanchez, Rojas, Pumares \& Fernandez, 2005; Navas, Rojas, Garcia \& Pumares, 2007) the findings of the present study show that female Arab students' acculturation expectations were not linear but dimension specific. Regardless of the ethnic group to which they belonged, all Arab students interviewed wished to integrate into higher education and in the Israeli job market. In contrast, although the interviewed students would have like to incorporate into their culture some of the values of the Western world such as independence and greater equality between genders, none of them wanted to assimilate into the Israeli culture. They were proud of being different and wanted to continue living in separate communities in order to preserve their own language, life style and cultural heritage.

In line with previous research in the field, the gossip to which the interviewees were subjected whenever they left their villages indicated the lack of appreciation if not the contempt of elderly women for higher education especially in the case of single women (Qassem, 2002). Consent of family members and alliance with the males among them was therefore, a necessary condition to meet community resistance and be able to access higher education (AbuRabia-Queder, 2008). 
With other research in the field the current research emphasizes the relationship between dominant language mastery, self-efficacy perception, and academic achievements of bilingual minority students (Biggs, 1976; Lerner, 2000; Silver \& Silver, 1997). Hebrew language proficiency was for Arab female students the first step toward competence acquisition, self-efficacy evaluation, and success in a culturally diverse environment.

In the colleges of higher education the encounter between knowledge, society, values and cultures often motivated female Arab students of various ethnic backgrounds to sort out their values and modify their perspectives and stereotypes about other ethnic groups (Barnett 1993; Bourdieu 1988). The cultural shock, otherness and alienation often reported by Arab women of various ethnic groups who had accessed Western- style universities in Israel were rarely if ever reported in the present study (Abu Rabia-Queder, 2008; Johnsurd \& Sadao 1998). The main shock experienced was rather related to the transition from Arabic to Hebrew, a language they seldom had used in the past and in which they had to study and communicate.

In contrast to previous research (Abu Rabia-Queder, 2008; Johnsurd \& Sadao 1998) reporting female Arab students' feelings of cultural alienation and otherness upon entering universities, no such feelings of were reported in this study. This finding may be explained by the fact that the Arab female students studying in the colleges of the Northern Galilee continued to live in their village, and studied with other Arab students of the same and nearby villages. The fact that Arab students constituted up to 50 percent of the student population and were visible portion of the student body in the colleges allowed to dissipate any feeling of otherness that these women might have experienced when studying at university centers. An additional explanation may be related to the fact that female Arab students commuted daily from their village to the college. The daily back and forth movement between cultures might have prevented the cultural shock and alienation from the culture of origin that Bedouin female students often reported upon return to the Bedouin village they had left when entering Israeli universities (Abu Rabia-Queder \& Weiner-Levi, 2008; Abu Rabia-Queder).

The findings of this study reinforce the view that inter-cultural patterns are dynamic, and evolving in interaction (Berry, 2005). Inter-ethnic group contact enhanced female Arab students' ability to sort out and integrate in their culture valued components from other cultures, while remaining proud of their own values and cultural heritage. This research also support assumptions of the additive model of cultural acquisition that has been compared to the code-switching multi-linguals engaged in (Liebkind, 2001; Phinney, 1990; Verkuyten, 2005). By the end of the third year of their studies, female Arab students who no longer experienced difficulty switching from Arabic to Hebrew were able to move from one culture to another and fit their behavior in the respective culture without compromising their own sense of self and cultural identity (Berry, 2005; Phinney, 2003).

Liebkind and McAlister (1997) have argued that increased contact between cultures was a necessary but not sufficient condition for the dissipation of inter-group prejudice. Attitude change was, for them, possible only when ethnic group members interacted as equals with other ethnic group members. Female Arab students' perception of equal status in academic colleges as opposed to the feeling of inferiority reported in the university may be related to the equal representation of Arab and Jewish students in the student population of the colleges and the development of confidence and self-efficacy perception resulting the mastery of the Hebrew language and related academic achievements.

The difference between town and villages was often stressed when addressing the lack of confidence exhibited by female Muslim and Druze students coming from secluded villages in the Galilee. These women often had no opportunity to develop oral Hebrew skills and initially felt less confident and more discriminated against than a comparable group of Muslim, or Christian female students who resided in large towns in which Arab and Jews lived next to each other in the same neighborhood.

However, as Hebrew language proficiency increased, so did academic success, self-confidence, and perceived feeling of equality. Nevertheless, personal acquaintance and friendship between various ethnic group members often took time to occur (Dovidio, Gaertner, \& Kawakami, 2003; Pettigrew \& Tropp; 2006). Distance and lack of frequent public transportation were central components limiting opportunities for inter-ethnic group contacts and joint participation in community events, and celebrations. The author also emphasizes that at no point in the interviews did the interviewees perceive themselves as Palestinians. They identified themselves as Christians, Druze, or Muslim Arab living in Israel and often noted that in Jordanian universities did not like Arab students from Israel. The same comments were reported by Arar \& Haj-Yehia (2010) in their study on Arab Israelis studying in Jordan.

The religious/ethnic breakdown of the Arab female students in the sample was 12 Druze, 22 Muslims and 8 Christians was not representative of the Arab population living in Israel which includes 80 percent of Muslims and 8 percent of Druze. Nevertheless, this ethnic profile corresponded to the ethnic composition of the Arab female student 
population in the two colleges examined. A possible explanation for this discrepancy is that Muslim women in the Galilee often pursue academic studies in Arab-speaking colleges in the region. Future studies could compare the acculturation expectations, and perception of tolerance and cultural diversity of female Muslim students pursuing a degree in Hebrew-speaking colleges vs. those studying in the Arabic language in local colleges.

The current study shows the importance of establishing academic colleges in the Northern Galilee as a means of widening Arab women's opportunity to access higher education and increasing intercultural contact. Pursuing academic studies in Hebrew their second language and being exposed to different mode of learning and thinking these women developed greater self-confidence and self-efficacy perception with increased Hebrew language proficiency and consequent academic success. In addition, the equal representation of Arab and Jewish minorities, and increased opportunities for intergroup contact in culturally-diverse classrooms promoted multicultural fluency and a strong sense of ethnic identity. Being able to appreciate valued elements in other cultures and traditions these women daily moved between cultures without feeling alienated when they returned home or fearing to lose their cultural identity when they arrived at the college. This study also stresses in the centrality of open-minded professors in the fight against prejudice and discrimination. By celebrating cultural diversity instructors motivate their students to respect each other and achieve multicultural fluency while remaining proud of their ethnic heritage and identity.

\section{References}

Abu-Asbah, K. (2005). The learning achievements of Arab students in Israel as a factor in their entry into the employment cycle and opportunities for change in their social status. In A. Paldi (Ed.), Education in the Test of Time. Tel Aviv: Teachers' Union Publication -- Reches Publishers-Educational Projects, pp. 627-646 [Hebrew].

Abu-Rabia-Queder, S. (2008). Does education necessarily mean enlightenment? The case of higher education among Palestinians-Bedouin women in Israel. Anthropology and Education Quarterly, 39(4) 381-400. http://dx.doi.org/10.1111/j.1548-1492.2008.00029.x

Abu-Rabia-Queder, S. \& Weiner-Levi, N. (2008). Identity and gender in cultural transitions: Returning home from higher education as "Internal Immigration" among Bedouin and Druze women in Israel', Social Identities, 14, 665-682. http://dx.doi.org/10.1080/13504630802462778

Abu-Saad, I. (2006). State-controlled education and identity formation among the Palestinian Arabs in Israel', American Behavioral Scientist, 49(8), 1085-1100. http://dx.doi.org/10.1177/0002764205284720

Ahmad, F. (2001). Modern tradition? British Muslim women and academic achievement. Gender and Education, 13, 137-152. http://dx.doi.org/10.1080/09540250120051169

Al-Haj, M. (1995). Education, empowerment and control: The case of the Arabs in Israel. New York: SUNY.

Al-Haj, M. (2003). Higher education among the Arabs in Israel: Formal policy between empowerment and control. Higher Education Policy, 16 (3), 351-368. http://dx.doi.org/10.1057/palgrave.hep.8300025

Arar, K., \& Haj-yehia, K. (2010). Emigration for Higher Education: The Case of Palestinians living in Israel studying in Jordan. Higher Education Policy,23(3), 358-380. http://dx.doi.org/10.1057/hep.2010.13

Astin, A.W. (1982). Minorities in American higher education, San Francisco, CA: Jossey-Bass.

Barnett, R. (1993). The idea of higher education. Buckingham: SRHE and Open University Press.

Berry, J.W. (1998). Acculturative stress. Florence: Taylor and Frances Routledge.

Berry, J. W. (2005). Acculturation: Living successfully in two cultures. International Journal of Intercultural Relations, 29:697-712. http://dx.doi.org/10.1016/j.ijintrel.2005.07.013

Berry, J. (2006). Contexts of acculturation/Stress perspectives on acculturation. In D. L. Sam \& J. W. Berry (Eds.). The Cambridge Handbook of Acculturation Psychology. (pp. 27-57). Cambridge: Cambridge University Press. http://dx.doi.org/10.1017/CBO9780511489891.006

Biggs, J. B. (1976). Dimensions of study behaviour. British Journal of Educational Psychology, 46, 68-80. http://dx.doi.org/10.1111/j.2044-8279.1976.tb02987.x

Bourdieu, P. (1988). Homo Academiecus. Cambridge: Polity.

Bourhis, R. Y., Moise, L. C., Perreault, S., \& Senecal, S. (1997). Towards an interactive acculturation model; A social psychological approach. International Journal of Psychology, 32, 369-386. http://dx.doi.org/10.1080/002075997400629

Bruner, J. (1990). Acts of meaning. Cambridge, MA: Harvard University Press 
Connor, H. (2004). Why the Difference? A closer look at higher education. Minority Ethnic Students and Graduates, London: Institute of Employment Studies.

Corradi, C, (1991). Text, context and individual meaning: Rethinking life stories in a hermeneutic frame. Discourse and Society 2(1):105-118. http://dx.doi.org/10.1177/0957926591002001006

Council for Higher Education. (2009). Planning and Budgeting Committee 34/35 report. Retrieved July 20, 2010 from http://www.che.org.il/download/files /contents_1.pdf (Hebrew).

Davidovitch, N. Soen, D. \& Kolan, M. (2007). Cultural framework and objective obstacles of Arab students in two public colleges in Israel. Higher Education in Europe, 32 (4), 359 - 368. http://dx.doi.org/10.1080/03797720802066237

Deardorff, M. \& Jones, A. (2004). Implementing affirmative action in higher education to Gratz and Grutter. Paper written in preparation for the American Political Association Annual Meeting held in Chicago, Illinois, 1-5 September.

Denzin, N. K. (1989). Interpretive interactionism. Newbury Park, CA: Sage.

Driessen, G. (2000). The limits of educational policy and practice? The case of ethnic minorities in The Netherlands. Comparative Education, 36, 55-72. http://dx.doi.org/10.1080/03050060027764

Dovidio, J. F., Gaertner, S. L., \& Kawakami, K. (2003). Intergroup contact: The past, present, and the future. Group Processes \& Intergroup Relations, 6, 5-20. http://dx.doi.org/10.1177/1368430203006001009

Gamliel, E. \& Cahan, S. (2004). Unfairness in university screening procedures: A modern version of the bible parable of the "Poor Man's Sheep. Magamot 3 : 433-445 [Hebrew].

Golub, J.E. (2009). The Galilee, Israel: Self-evaluation report. OECD Reviews of Higher Education in Regional and City Development. Council for Higher Education of the State of Israel. http://www.oecd.org/edu/imhe/

Hasan, M. (1999). The politics of honour: patriarchy, the state, and the murder of women in the name of family honour. In Izraeli, D., Friedman, A., Dahan-Kalev, H., Fogiel-Bijaui, S. Herzog, H., Hasan, M., \& Naveh, H. (Eds). Sex, gender, and politics: Women in Israel (pp 267-305). Hakibbutz Hameuchad Publishing, Tel-Aviv (original in Hebrew)

Hershkovitz, S. (2000). Expanding Access to higher education. Jerusalem: The Commission for Higher Education, Planning and Budget Committee. [In Hebrew].

Holsti, O. (1969). Content analysis for social science and humanistics. Reading, MA: Addison-Wesley.

Johnsurd, L. \& Sadao, K. (1998). The common experience of "otherness": ethnic and racial minority faculty, The Review of Higher Education 21 (4): 315-342. http://dx.doi.org/10.1353/rhe.1998.0010

Krueger, R. \& Casey, M. (2000). Focus group interviews: A practical guide for applied research (3rd ed). Newbury Park, CA: Sage.

Layish, A. (1992). The Arabs in Israel: Continuity and change. Givat Haviv: Institution for Arab Studies.

Lerner, Y. (2000). The Path of knowledge: Russian immigrants in universities. Jerusalem: Shein Institute for Social Study Research.

LeVine, R. A., \& Campbell, D. T. (1972). Ethnocentrism: Theories of conflict, ethnic attitudes and group behavior. New York: Wiley.

Liebkind, K. (2001). Acculturation. In R. Brown, \& S. Gaetner (Eds.), Blackwell handbook of social psychology, Vol. 3. Intergroup processes. Oxford, Blackwell: 386-406.

Liebkind, K. \& McAllister, A. (1997). Extended contact through peer modeling to promote tolerance in Finland. European Journal of Social Psychology, 29, 765-780. http://dx.doi.org/10.1177/0165025407081474

Lincoln, Y. S. \& Guba, E.G. (1985). Naturalist inquiry. Newbury Park, CA: Sage.

Manna, A. (2008). Arab society in Israel (2) Population, society, economy, Jerusalem: Van Leer Institute [Hebrew].

Mazawi, A. (2003). Concentration of disadvantage in resources and accessibility to matriculation certificates in Arab and Jewish settlements in Israel. In Y. Dror, D. Nevo, and R. Shapira (Eds.) Changes in Education -- Outlines for Education in Israel in The 20th Century, Tel Aviv: Ramot Publications [Hebrew], pp. 56-57. 
Mustafa, M. (2006). Higher education among the Palestinians in Israel, Umm al Fahum: "Akraa" Association for the Advance of Education in Arab Society [Arabic].

Navas, M., Garcia, M. C., Sanchez, J., Rojas, A. J., Pumares, P., \& Fernandez, J. S. (2005). Relative acculturation extended model (RAEM): New contributions with regard to the study of acculturation. International Journal of Intercultural Relations, 29(1), 21-37.350. http://dx.doi.org/10.1016/j.ijintrel.2005.04.001

Navas, M., Rojas, A. J., Garcia, M. C., \& Pumares, P. (2007). Acculturation strategies and attitudes according to the relative acculturation extended model (RAEM): The perspectives of natives versus immigrants. International Journal of Intercultural Relations, 31(1), 67-86. http://dx.doi.org/10.1016/j.ijintrel.2006.08.002

Nissim, D. (2003). The Druze in the Middle East. London: Sussex Press.

Ntiri, D. (2001). Access to higher education for nontraditional students and minorities in a technology focused society. Urban Education 36 (1): 129-144. http://dx.doi.org/10.1177/0042085901361007

Patton M. Q. (2002). Qualitative research and evaluation methods. (3rd ed.) Thousand Oaks, CA: Sage Publications.

Phinney, J. (2003). Ethnic identity and acculturation. In K. Chun, P. Organista \& G. Marin (Eds.), Acculturation: Advances in theory, measurement, and applied research. Washington DC, American Psychological Association: 63-81. http://dx.doi.org/10.1037/10472-006

Phinney, J. S. (1990). Ethnic identity in adolescents and adults: Review of research. Psychological Bulletin, 108(3), 499-514. http://dx.doi.org/10.1177/0743558403260098

Pettigrew, T. \& Tropp, L. (2006). A meta-analytic test of intergroup contact theory. Journal of Personality and Social Psychology, 90, 751-783. http://dx.doi.org/10.1037/0022-3514.90.5.751

Rosenthal, G. (1994). Reconstructing of life stories: Principles of selection in generating stories for narrative biographical interviews. In R. E. Josselson and A. Lieblich (Eds), The narrative study of lives,(pp. 30-59). London: Sage.

Shiner, M. \& Modood, T. (2002). Help or hindrance? Higher education and the route to ethnic equality, British Journal of Sociology of Education 23 (2): 209-232. http://dx.doi.org/10.1080/01425690220137729

Silver, H. \& Silver, P. (1997). Students: Changing roles, changing lives. Buckingham, UK: SHRE and the Open University.

Sodowsky, G.R. \& Plake, B.S. (1992). A study of acculturation differences among international people and suggestions for sensitivity to within-group differences Journal of Counselling and Development, 71, 53-59. http://dx.doi.org/10.1002/j.1556-6676.1992.tb02171.x

Strauss, A. (1987). Qualitative analysis for social scientists. Cambridge: Cambridge University Press. http://dx.doi.org/10.1017/CBO9780511557842

Vedder, P. (2005). Language, ethnic identity, and the adaptation of immigrant youth in the Netherlands. Journal of Adolescent Research, 20, 396-416. http://dx.doi.org/10.1177/0743558405274853

Verkuyten, M. (2005). The social psychology of ethnic identity. European Monographs in Social Psychology. New York: Psychology Press. http://dx.doi.org/10.4324/9780203338704

Ward, C., Bochner, S., \& Furnham, A. (2001). The psychology of culture shock. Sussex: Routledge.

World Conference against Racism, Racial Discrimination, Xenophobia and Related Intolerance. (August 31-Sept. $8^{\text {th }}$ 2001). Declaration, paragraphs 95 and Programme of Action, paragraphs 129-136. Durban, South Africa.

Weisblai, A. (August, 2007). Higher education report on access and difficulties encounters by Arab population in Israel. Retrieved on 15/10/2009 www.knesset.gov.il/mmm/data/docs/m01982.do [in Hebrew].

Weiner-Levy, N. (2006). The flagbearers: Israeli Druze women challenge traditional gender roles. Anthropology and Education Quarterly 37(3):217-235. http://dx.doi.org/10.1525/aeq.2006.37.3.217 